\title{
Assessment of Variability and Response to Selection for Earliness and Curd Size in Cauliflower cv. soultani Under Assiut Environmental Conditions
}

\author{
E. F. S. Refai ${ }^{* *}$, H. S. Abbas* and M. F. Mohamed ${ }^{*}$ \\ *Department of Vegetable Crops, Faculty of Agriculture, Assiut University, Assiut and \\ ${ }^{* *}$ Horticulture Research Institute, Agricultural Research Centre, Cairo, Egypt.
}

\begin{abstract}
$\mathbf{T}$ HE PRESENT study was conducted during three consecutive winter seasons (2015 to 2017). Assessment of the variability and genetic associations within a population of the local cauliflower cv. Soultani along with the response to phenotypic positive mass-selection for days to visible curd (DVC) and curd diameter (CD) were studied. Further, field performance of concurrently evaluated base $(\mathrm{C} 0)$ and both first $(\mathrm{C} 1)$ and second $(\mathrm{C} 2)$ cycle populations was conducted. Data analysis showed a wide range of variation in the primary (DVC and CD) and secondary (plant length PL, number of leaves NL, curd weight $\mathrm{CW}$ and total plant weight TPW). All traits had low negative correlation coefficients $\left(r_{g}\right)$ with DVC while they showed high positive values with $\mathrm{CD}$. The response (R) of DVC to selection, as percent of mean, was low due to the existence of a predominant non-additive gene action. However, $\mathrm{CD}$ exhibited a moderate $\mathrm{R}$ to selection in $\mathrm{C} 1$ that declined in $\mathrm{C} 2$. The highest correlated response (CR) was for the $\mathrm{CW}$ in $\mathrm{C} 1$ but no appreciable $\mathrm{R}$ occurred in $\mathrm{C} 2$. Estimated indirect selection efficiency for all secondary traits was less than one. Concurrent field evaluation showed significant differences among the three populations $(\mathrm{C} 0, \mathrm{C} 1$ and $\mathrm{C} 2)$. Relative to $\mathrm{C} 0$, the $\mathrm{C} 2$ population had $57 \%$ higher total yield and $114 \%$ early yield. The DVC showed a reduction of $11.7 \%$ and CD elevated $47.6 \%$. We concluded that directive positive mass-selection can practically be efficient in improving our cauliflower landraces.
\end{abstract}

Keywords: Correlated response to selection, Cauliflower improvement, Directional selection, Genetic gain, Indirect selection, Positive mass-selection.

\section{Introduction}

Cauliflower is a vegetable crop in the genus Brassica, species oleracea and Botrytis group of the family Brassicaceae. It is an annual plant reproduces by seeds. The head is the edible part and it is called "curd". The cauliflower head is composed of flower buds which commonly are white. However, orange head contains betacarotene, green (broccoflower) and purple caused by the presence anthocyanin's exist. Broccoli, Brussels sprouts, cabbage, collard greens and kale belong to Brassica oleracea. Collectively, they are called "Cole" crops. The total area cultivated with Cauliflower and Broccoli in Egypt was 10480 feddan and the total production 124963 tons (FAOSTAT, 2016).

Cauliflower plants have to be subjected to certain level of chilling to initiate curds (Booij and Struik, 1990, Mohamed et al., 2014). The plants respond to the low temperature after ending of a certain juvenile growth phase. Cultivars differ in their requirements of the inductive low temperature, duration necessary for thermoinduction and the length of juvenility phase (Fujime, 1988, Abdel-Rahman, 2011, Mohamed et al., 2014). Therefore, cultivars are classified into early, medium and late (Morsi and El-Murabaa, 1960). Soultani cultivar in well adapted to the environmental conditions in Egypt and it has low inductive chilling requirements. It is considered, therefore, a summer cultivar type (Hasan, 1991) since it is planted as early as April to June. Thus production season of cauliflower can cover most of the year.

The local cultivar of Soultani is characterized by its relatively large heads which has a whiteyellowish color (Hasan, 1991). However,

Corresponding author : Hassan S. Abbas, e-mail:hassanabbas654@yahoo.com

DOI : 10.21608/ejoh.2019.9973.1099

(C)2019 National Information and Documentation Centre (NIDOC) 
the production of this cultivar may suffer underdeveloped head and buttoning. This is due to cross-pollination and fertilization while produced by local farmers/firma of little awareness concerning the good practices for seed production. Positive and negative mass-selections have been found potential to improve local germplasm cultivars (Mohamed, 1996). Mass-selection can be practiced in both self- and cross-pollinated crops and it is simple. Reports on assessment of massselection potentiality to improve the cauliflower Soultani cv. performance are lacking. The objectives of the current study, therefore, were to: 1) assess variability and statistically characterize a population of local cv. Soultani, 2) study the response to direct and indirect (correlated) massselection, and 3) concurrent evaluate of the base population along with two populations of two mass-selection cycles.

\section{Materials and Methods}

The present study was conducted in the Research Farm of the Department of Vegetable Crops, Faculty of Agriculture, Assiut University, Egypt during the growing winter seasons of 2015, 2016 and 2017. The local cv. Soultani was used. Seeds of this cultivar were obtained from local seed retailer and the same seed lot was used in the whole course of the current research study. In all experiments, seeds were planted in nursery in 244hole plastic trays filled with washed sand and peatmoss $(1: 1, \mathrm{v}: \mathrm{v})$. The produced transplants were grown in the open field on northern side of $70 \mathrm{~cm}$ wide ridges and at $50 \mathrm{~cm}$ within row spaces. All cultural practices were followed as recommended under Upper Egypt conditions (Hasan, 1991).

\section{Mass-Selection scheme}

In 2015, seeds were planted in nursery on June, 11 to produce the base population (C0). A total of 467 plants were established in the open field. The primary selection criterions were the earliness in terms of days to produce visible curds and the curd size expressed as diameter. It is noticeable here to mention that earliness in days to produce visible curds was decided as primary selection trait because it implies low chilling requirements to initiate curds. Curd diameter was chosen as it is needed to produce seeds from the selected plants for next generation while it implies for curd weight. Eighteen plants were selected in 2015 from C0. All remaining plants were culled out. The 18 selected plants were left for the open pollination among themselves where the area was surrounded by Brassica crop free zone of at least
$2 \mathrm{~km}$. The produced seeds were harvested at the end of the season. An equal amount of seeds from each plant were mixed and used to produce the first cycle $(\mathrm{C} 1)$ population.

In 2016, C1 seeds were planted on June 12 and transplants were grown in the open field the same as described above. The total open field established plants were 409 . Twenty-six plants were selected from $\mathrm{C} 1$ population to produce $\mathrm{C} 2$ population. In 2017, C2 seeds were planted in isolated location for further population characterization study and assessment of response to selection. At the same time, $\mathrm{C} 0, \mathrm{C} 1$ and $\mathrm{C} 2$ were grown for simultaneous evaluation in a separate experiment designed as randomized complete-blocks with four replicates. These three populations were planted on June 17. The experiment unit contained 5 rows each of $3 \mathrm{~m}$ long and $0.7 \mathrm{~m}$ wide. Six plants were in each row.

\section{Measured parameters}

All measured parameters were recorded on an individual plant basis. The following traits were studied for the populations during both the progressive process of the selection and during the final simultaneous evaluation of the three populations:

- days to visible curd.

- curd diameter.

- leaf number at harvest.

- plant height at harvest.

- curd weight and total plant weight.

Additionally, total curd yield and early curd yield (yield of the first three harvests) per feddan were recorded for the final simultaneous evaluation of the three populations.

\section{Statistical Procedure}

Basic statistical parameters characterizing the populations during the process of the massselection cycles $(\mathrm{C} 0, \mathrm{C} 1$ and $\mathrm{C} 2)$ were estimated. These included the range, mean, variance, standard deviation (SD), standard error (SE), Skewness and Kurtosis. Expected selection response (R) was estimated (Allard 1960; Falconer, 1989) as $\mathrm{R}=\mathrm{i}_{*} \mathrm{~h}^{2}$ õP, where $\mathrm{i}$ is standardized selection differential, $h^{2}$ is the heritability in broad sense and õP is the phenotypic standard deviation. Based on the variance component (Steel and Torrie, 1980) of the analysis of variance relevant to RCBD design (Gomez and Gomez, 1984), genotypic and phenotypic variances $(\mathrm{Vg}$ and $\mathrm{Vp})$ were estimated. The $\mathrm{VG}=\left(\mathrm{MS}_{\mathrm{G}}-\mathrm{MS}_{\mathrm{E}}\right) / \mathrm{r}$, where $\mathrm{MS}_{\mathrm{G}}$ is the means squared of genotypes, $\mathrm{MS}_{\mathrm{E}}$ is the means square of the residual (error), and $\mathrm{r}$ is the 
number of replication. $\mathrm{V}_{\mathrm{P}}=\mathrm{V}_{\mathrm{G}}+\left(\mathrm{MS}_{\mathrm{E}} / \mathrm{r}\right)$. The broad sense heritability was calculated as $\mathrm{H}^{2}=\mathrm{Vg}$ /Vp (Mather, 1949) where Vg $=(\mathrm{Vp}-\mathrm{Ve})$. The correlated response to selection was estimated as $\mathrm{CRy}=\mathrm{i}_{*} \mathrm{HxHy}_{*} \mathrm{rg}_{*} \tilde{\mathrm{O}} \mathrm{P}_{\mathrm{y}}$ where $\mathrm{i}$ the standardized selection differential for traits $\mathrm{x}, \mathrm{Hx}$ and $\mathrm{Hy}-$ the square roots of heritability of traits $x$ and $y, r_{g}$ is genetic correlation between $\mathrm{x}$ and $\mathrm{y}$ and $\mathrm{oP}_{\mathrm{y}}$ is the phenotypic standard deviation for $y$ (Falconer, 1989). Relative efficiency of indirect selection (E) is calculated (Gizaw et al., 2016) as the ratio of CRy and $\mathrm{Rx}$ : $\mathrm{E}=\mathrm{CRy} / \mathrm{Rx}=\mathrm{i}_{\mathrm{y}^{*}} \mathrm{r}_{\mathrm{g}} \mathrm{Hy} / \mathrm{i}_{\mathrm{x}} \mathrm{Hx}$ where CRy is the correlated response of trait $y$ and $R x$ is direct response of trait $\mathrm{x}, \mathrm{rg}$ is genetic correlation between the two traits, $\mathrm{Hy}$ and $\mathrm{Hx}$ are square roots of broad sense heritability for the secondary trait and primary trait, respectively. The genetic correlation $\left(r_{g}\right)=\operatorname{Cov}_{g} X Y / \tilde{o}_{g} Y_{*} \tilde{o}_{g}$, where $\operatorname{Cov}_{g} X Y$ is genetic covariance between traits $\mathrm{x}$ and $\mathrm{y}$, and $\tilde{\mathrm{o}}_{\mathrm{g}} \mathrm{X}_{*} \tilde{\mathrm{o} g \mathrm{Y}}$ is the product of the square root of genetic variances of traits $\mathrm{x}$ and $\mathrm{y}$, respectively (Miller, et al, 1958; Searle, 1961; Kashiani, and Saleh, 2010). The mean separation of the simultaneously evaluated three populations $(\mathrm{C} 0, \mathrm{C} 1$ and $\mathrm{C} 3)$ at the end of the two selection cycles was achieved using the least significant difference at $\mathrm{P} \leq 0.05$.

\section{Results}

Statistical characterization of the base and selection-derived populations

Central tendency (means) and dispersion (variance and standard deviation) measures, in addition to, shape descriptors (skewness and kurtosis) are presented in Table 1. The values of skewness and the excess kurtosis of the base and both the first and second cycle populations $\left(\mathrm{C}_{0}\right.$, $\mathrm{C}_{1}$ and $\mathrm{C}_{2}$ ) reveal a nearly normal distribution of the days to visible curd. With few exceptions, crud diameter, plant height, leaf number, crud weight and total plant weight seemed to have a distribution close to normal.

TABLE 1. Basic statistical descriptors of a base (C0) and two cycles (C1 and C2) of mass-selection derived populations for cauliflower landrace cv Soultani grown in Assiut, 2015 to 2017.

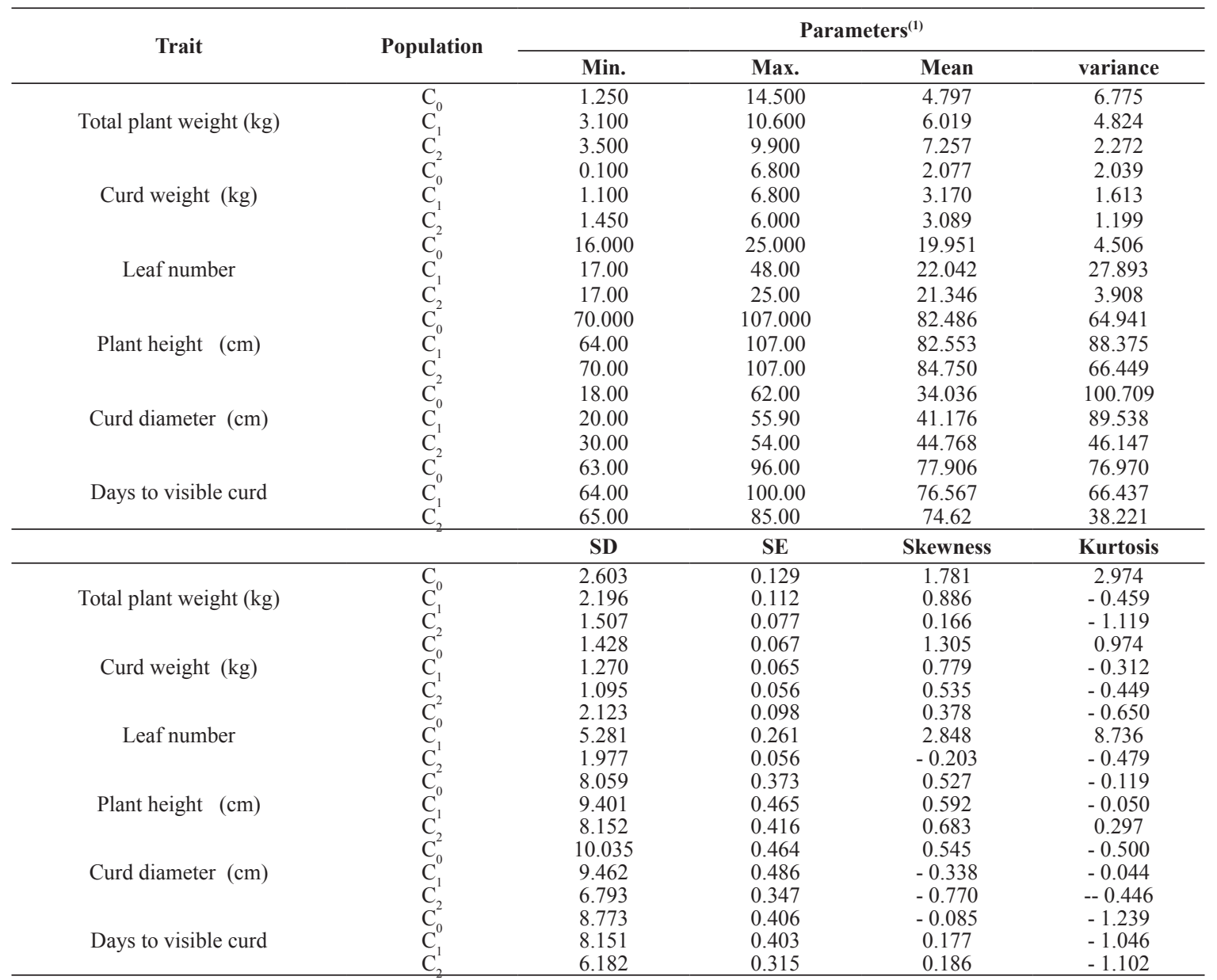

${ }^{(1)} \mathrm{SD}=$ population standard deviation; $\mathrm{SE}=$ standard deviation for means (standard error). 
Days to visible curd of the cauliflower base population $\left(\mathrm{C}_{0}\right)$ ranged from $63 \mathrm{~d}$ to $96 \mathrm{~d}$ with an arithmetic mean of $77.9 \mathrm{~d}$. The difference between the lower and higher limits of the range was $33 \mathrm{~d}$. The offspring of the parents $\left(\mathrm{C}_{1}\right)$ selected from the $\mathrm{C}_{0}$ showed closely similar range and range limits and mean value for days to visible curd. However, the progeny of the second selection cycle $\left(\mathrm{C}_{2}\right)$ showed 11 to $15 \%$ reduction in the upper limit value of the range. In alignment with the results of the range and means data, $\mathrm{C}_{2}$ seemed relatively more uniform as expressed by reduced variance values.

The crud diameter of the base cauliflower population plants had range of $44 \mathrm{~cm}(18-62$ $\mathrm{cm})$. The range maximum value reduced $7 \mathrm{~cm}$ (from 62 to 55) in $\mathrm{C} 1$ and $8 \mathrm{~cm}$ (from 62 to 54) in $\mathrm{C} 2$. The minimum value increased $2 \mathrm{~cm}$ (from 18 to 20 ) and 12 (from 18 to $30 \mathrm{~cm}$ ) in the $\mathrm{C}_{1}$ and $\mathrm{C}_{2}$ populations, respectively. These changes accompanied by a decrease of $9 \mathrm{~cm}$ (from 44 to 35 ) and $20 \mathrm{~cm}$ (from 44 to 24 ) in the range value of $\mathrm{C} 1$ and $\mathrm{C} 2$ populations, respectively. The variance also decreased from 100.709 in $\mathrm{C} 0$ to 89.538 in $\mathrm{C} 1$ and to $46.147 \mathrm{~cm}$ in the $\mathrm{C} 2$. Controversially, means rose from 34.036 to 42.176 in $\mathrm{C} 1$ and to $44.768 \mathrm{~cm}$ in $\mathrm{C} 2$.

Plant height did not show a clear trend of alteration in the different selection cycles and seemed unchanged regarding minimum and maximum values, variances and means. Number of leaves, likewise, did not exhibit clear alterations. Curd weight had $6.7 \mathrm{~kg}$ as a difference between maximum and minimum values. This difference decreased to $5.7 \mathrm{~kg}$ in $\mathrm{C} 1$ without a change in the maximum value. Variance decreased and the mean increased in $\mathrm{C} 1$. In $\mathrm{C} 2$, the range decline to 4.55 $\mathrm{kg}$ with unchanged mean and a reduced variance. The total plant weight exhibited a rather regular trend where the range and variance seemed to steadily diminish while means was rising.

\section{Direct and correlated responses to selection}

Data in Table 2 show the expected and realized direct and correlated responses to directional mass- selection for the two selection cycles in cauliflower cv Soultani grown in Assiut during the winter seasons of 2015, 2016 and 2017. It is clear that the expectation for days to visible curd was much greater than the realized values in both selection cycles (Table $2 \mathrm{~A}$ ). The expected response was 13.38 and 7.87 folds greater for $\mathrm{C} 1$ and $\mathrm{C} 2$, respectively. Controversially, almost Egypt. J. Hort. Vol. 46, No.1 (2019) all correlated responses correlated with days to visible curd as primary selection criterion had greater realized than expected values (Table $2 \mathrm{~B}$ to F).

The expected correlated response of selection for leaf number (Table $2 \mathrm{~B}$ ) was higher than the realized one in $\mathrm{C} 1$ but lower in $\mathrm{C} 2$. It changed from -0.196 to 2.091 in $\mathrm{C} 1$ and from -0.617 to -0.696 in C2. Plant height (Table 2 C) showed an increased expected correlated response in both cycles of selection but the elevation seemed larger in $\mathrm{C} 2$. The expected correlated response to selection for crud weight was higher than the realized one in both selection cycles. It changed from -0.281 to 1.039 (4.889 times greater) in $\mathrm{C} 1$ and from -0.266 to -0.081 (1.305 times greater) in C2. Obviously, both expected and realized selection responses were higher in $\mathrm{C} 1$ than in $\mathrm{C} 2$ for both days to harvest and crud weight.

Total plant weight exhibited elevation in realized correlated response to selection in both $\mathrm{C} 1$ and $\mathrm{C} 2$ (Table 2E). Apparently, substantially increased values of realized correlated response occurred in $\mathrm{C} 1$ and $\mathrm{C} 2$ for crud diameter (Table 2 F). Direct selection for curd diameter was estimated to produce curds with an increase of $14.886 \mathrm{~cm}$ in $\mathrm{C} 1$ and $12.927 \mathrm{~cm}$ in $\mathrm{C} 2$. The realized response showed $7.14 \mathrm{~cm}$ and $2.392 \mathrm{~cm}$ increase for curd diameter in $\mathrm{C} 1$ and $\mathrm{C} 2$, respectively. Values of the expected correlated response following the direct selection of curd diameter (Table $2 \mathrm{~L}$ ) were much higher than those for following direct selection of days to visible curd. For example, expected curd weight (Table $2 \mathrm{D}$ vs J) was 2.163 vs. -0.281 in $\mathrm{C} 1$ and 1.652 vs. -0.266 in $\mathrm{C} 2$.

Data in Table 3 indicate the realized selection response calculated as percent of the relevant selection cycle mean $(\mathrm{C} 0$ or $\mathrm{C} 1)$. The higher percent was found in $\mathrm{C} 1$ for curd weight and the lower one was -3.16 in $\mathrm{C} 2$ for leaf number. The efficiency of indirect selection (Table 3) showed that all values, except curd weight in $\mathrm{C} 1$, were less than 1 . Therefore, no secondary trait may be useful for selection of days to harvest or curd diameter in the population studied of cauliflower cv. Soultani. All genetic correlation coefficients (rg) of the studied traits were low and negatively associated with days to harvest. On the other hand, all $\mathrm{r}_{\mathrm{g}}$ with curd diameter were high and positive. 
TABLE 2. Expected and realized direct ( $A$ and $G$ ) and correlated ( $B$ to $F$ and $H$ to $L$ ) responses to mass selection for two selection cycles (C1 and C2) in cauliflower grown in Assiut, 2015 to 2017.

\begin{tabular}{|c|c|c|c|}
\hline & \multirow[t]{3}{*}{ Selection cycle ${ }^{(1)}$} & \multicolumn{2}{|c|}{ Traits } \\
\hline & & (A) & (G) \\
\hline & & Days to visible curd & Curd diameter $(\mathrm{cm})$ \\
\hline \multirow{2}{*}{$\mathrm{C} 1$} & Expected & -17.918 & 14.886 \\
\hline & Realized & -1.339 & 7.14 \\
\hline \multirow{4}{*}{$\mathrm{C} 2$} & Expected & -15.332 & 12.927 \\
\hline & Realized & -1.947 & 3.592 \\
\hline & & (B) & (H) \\
\hline & & Leaf number & Leaf number \\
\hline \multirow{2}{*}{$\mathrm{C} 1$} & Expected & -0.196 & 4.379 \\
\hline & Realized & 2.091 & 2.091 \\
\hline \multirow{4}{*}{$\mathrm{C} 2$} & Expected & -0.617 & 4.547 \\
\hline & Realized & -0.696 & -0.696 \\
\hline & & (C) & (I) \\
\hline & & Plant height $(\mathrm{cm})$ & Plant height $(\mathrm{cm})$ \\
\hline \multirow{2}{*}{$\mathrm{C} 1$} & Expected & -0.119 & 5.25 \\
\hline & Realized & 0.067 & 0.067 \\
\hline \multirow{4}{*}{$\mathrm{C} 2$} & Expected & -0.846 & 5.776 \\
\hline & Realized & 2.197 & 2.197 \\
\hline & & (D) & (J) \\
\hline & & Curd weight (kg) & Curd weight (kg) \\
\hline \multirow{2}{*}{$\mathrm{C} 1$} & Expected & -0.281 & 2.163 \\
\hline & Realized & 1.093 & 1.093 \\
\hline \multirow{4}{*}{$\mathrm{C} 2$} & Expected & -0.266 & 1.652 \\
\hline & Realized & -0.081 & -0.081 \\
\hline & & (E) & (K) \\
\hline & & Total plant weight (kg) & Total plant weight (kg) \\
\hline \multirow{2}{*}{$\mathrm{C} 1$} & Expected & -0.337 & 1.942 \\
\hline & Realized & 1.222 & 1.222 \\
\hline \multirow{4}{*}{$\mathrm{C} 2$} & Expected & -0.406 & 2.849 \\
\hline & Realized & 1.238 & 1.238 \\
\hline & & (F) & (L) \\
\hline & & Curd diameter (cm) & Days to visible curd \\
\hline \multirow{2}{*}{$\mathrm{C} 1$} & Expected & -2.080 & -1.690 \\
\hline & Realized & 7.14 & -1.339 \\
\hline \multirow{2}{*}{$\mathrm{C} 2$} & Expected & -1.427 & -0.669 \\
\hline & Realized & 3.592 & -1.947 \\
\hline
\end{tabular}

${ }^{(1)}$ Selection intensity (i) $=2.15$ in C0 (i.e., $3.9 \%$ selected plants) and $\mathrm{i}=1.98$ in $\mathrm{C} 1$ (6.4\% selected plants).

TABLE 3. Realized selection response as percent of the population mean, the efficiency of indirect selection and genetic correlation coefficients for two mass selection cycles (C1 and C2) in cauliflower cv Soultani grown in Assiut, 2015 to 2017.

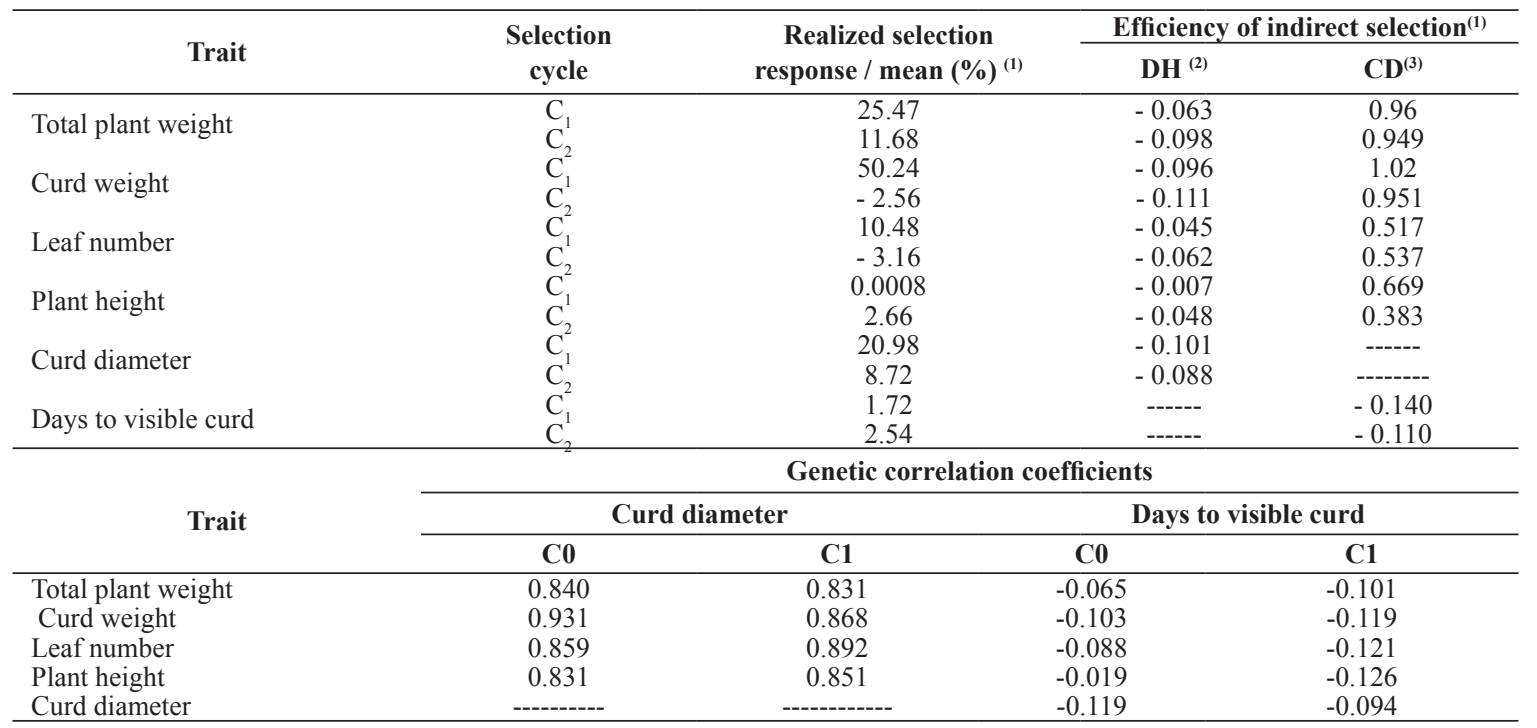

(1) Relative to base population ( $\mathrm{C} 0$ ) for estimation in $\mathrm{C} 1$ and relative to $\mathrm{C} 1$ population for estimation in $\mathrm{C} 2$.

(2) Selection based on days to visible curd as a primary trait

(3) Selection based on crud diameter as a primary trait. 
Performance of derived populations after two cycles of selection

The analysis of variance revealed the existence of significant variation among the three populations [the base $(\mathrm{C} 0)$ and the two selectionderived populations (C1), and $\mathrm{C} 2)]$. Mean comparisons indicated that $\mathrm{C} 2$ had the highest values total and early curd yield,, curd weight and total plant weight (Fig. 1). The $\mathrm{C} 2$ population had the least number of days to harvest. $\mathrm{C} 2$ population produced curds of great weight but $\mathrm{C} 1$ had a comparable value. $\mathrm{C} 1$ population, in comparison with $\mathrm{C} 0$, was superior regarding its total and early yield, days to visible curd, curd weight and total plant weight. Thus mass-selection improved the performance of the cauliflower cv. Soultani. Noticeably, there were no significant differences detected for the leaf number and plant height among the three populations.

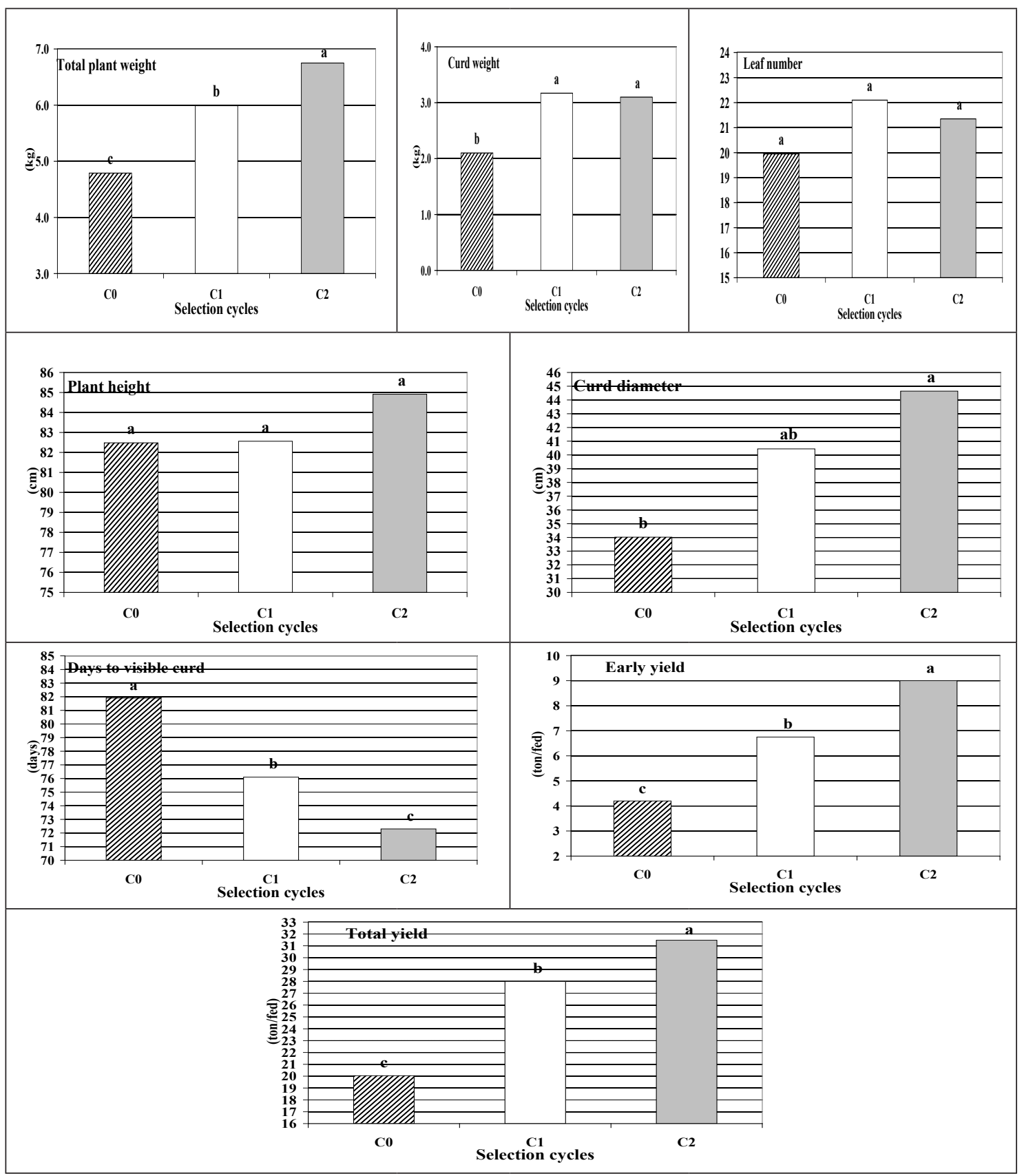

Fig. 1. Total plant weight $(\mathrm{kg})$, curd weight $(\mathrm{kg})$ leaf number, plant height $(\mathrm{cm})$, curd diameter $(\mathrm{cm})$, days to visible curd , early yield (ton/fed) and total yield(ton/fed) for base population (C0) and selection-derived first (C1) and second (C2) cycles populations of cauliflower landrace of cv. Soultani grown in Assiut, 2015 to 2017. Note: leaf number and plant height did not show significant differences among populations of the three selection cycles.

Egypt. J. Hort. Vol. 46, No.1 (2019) 


\section{Discussion}

The realized genetic advance of a trait under selection is controlled by several factors including the total variation, the selection pressure imposed and the heritability. Variability is a key factor and the greater the variability in the basic population, the greater is the possibility of improvement (Vidyadhar et al., 2007, RahalBouziane and Semiani, 2016). Regardless how high the heritability is, the genetic gain would be little without an existence of high genetic variation. Selection depletes the genetic variation and consequently reduces the heritability. Thus selection response from generation to next one declines but the mean value of the trait raises or lessens, depending on the nature of the trait.

Considering the variation in the present study, the primary traits (days to visible curd and curd diameter) exhibited great phenotypic variation. The days to visible curd had 33 days difference between earliest and latest plant in the base population (C0). This difference shrank to 20 days after two cycles of mass-selection. Sharp decline occurred in variance where it changed from 76.97 in $\mathrm{C} 0$ to 66.437 in population after one cycle of mass selection (C1) then to 38.221 in population after two cycles of mass-selection (C2). Likewise, curd diameter showed $44 \mathrm{~cm}$ difference between the smallest and the biggest one in $\mathrm{C} 0$. This variation became $35 \mathrm{~cm}$ in $\mathrm{C} 1$ and $24 \mathrm{~cm}$ in $\mathrm{C} 2$. Variance change pattern was closely similar where it declined from 100.709 in $\mathrm{C} 0$ to 89.536 in $\mathrm{C} 1$ and then to 46.147 in $\mathrm{C} 2$. It is noticeable that both primary traits were nearly normally distributed as indicated by the skwness and kurtosis values. Generally, two secondary traits (curd weight and plant total weight) behaved similarly to some extent concerning the existence and changes of the variability. The other two secondary traits (plant height and curd weight) had less pronounced variability.

Realized selection response for the primary traits is underestimated as compared to the expected response. Days to visible curd, particularly, is much low in this context. The realized selection response as percent of the mean for this trait was $1.72 \%$ in $\mathrm{C} 1$ and $2.54 \%$ in $\mathrm{C} 2$. This occurred in spite of the high heritability $\left(\mathrm{H}^{2} ; 0.95\right)$ estimated for it. Since expected selection response is based here on the broad sense heritability estimates, then the days to visible curd is controlled largely by non-additive gene action. Curd diameter $\left(\mathrm{H}^{2}\right.$
0.69 ), on the other hand, showed a realized gain of $20.98 \%$ in $\mathrm{C} 1$ and $8.72 \%$ in $\mathrm{C} 2$. The reduced response to selection in this case can be attributed to an influence of large environmental factors (Peter Visscher et al., 2008). However, a portion of the reduced percent of realized response may be ascribed to non-additive gene action. The reduction of the variability of curd diameter after one cycle of selection $(\mathrm{C} 1)$ could be an additional cause for the much low response value in $\mathrm{C} 2$ $(8.72 \%)$.

Several factors affect the improvement of quantitative traits. These include the polygenic nature and low heritability, linkage, non-additive gene action and environmental effects. Therefore, it is necessary to get information about genetic structure of the population undergoing selection. In the current study, genetic correlation coefficients $\left(r_{g}\right)$ for days to visible curd were low and negative with curd diameter and all the secondary traits in both of $\mathrm{C} 0$ and $\mathrm{C} 1$. Dissimilarly, the curd diameter gave positive high to moderately high coefficients with all secondary traits. Therefore, all expected correlated responses had negative sign and were less than the realized ones. On the other hand, expected responses of curd diameter were positive and greater than the realized values of genetic gain. Genetic correlation is the proportion of variance that two traits share due to genetic causes. The highest percent of correlated selection response was found for the secondary trait curd weight in $\mathrm{C} 1$. This may attribute to its high heritability $\left(\mathrm{H}^{2}=0.83\right)$ and its high genetic correlation with the primary trait curd diameter. However, depletion of potential variation and using higher selection intensity $(3.9 \%, \mathrm{i}=2.15$ in C0 compared with $6.4 \%, \mathrm{i}=1.98$ in $\mathrm{C} 1$ ) led to almost no response in $\mathrm{C} 2$.

Effective selection can be realized through usage of appropriate breeding method and availability of reliable selection criteria for the identification of the most productive genotypes (Borghi et al., 1998). It is worth to mention that the low and negative $r_{\mathrm{g}}$ for days to visible curd is advantageous for the population of cauliflower used here as it is an indication for possible selection of early plants with large curds. Biologically this is sensible for the cauliflower cv. Soultani since it has low chilling requirements for flowering induction. Another advantageous for this cauliflower cv. Soultani population is the high $\mathrm{r}_{\mathrm{g}}$ between curd diameter and curd weight. Thus 
selection can be practiced using curd diameter as nondestructive selection criterion for improving curd diameter. Efficiency of indirect selection for days to visible curd and curd diameter was $<1$. Markedly, none of the secondary traits had potential to be used as indirect selection criterion for early and great curd diameter.

As shown by the final concurrent evaluation of the three populations $(\mathrm{C} 1, \mathrm{C} 2$ and $\mathrm{C} 3)$, the phenotypic mass-selection was ended up with a population that had improved total curd yield $(57 \%)$, early yield (114\%), days to visible curd $(11.7 \%)$ and curd diameter $(47.6 \%)$ relative to the base population. Obviously, days to visible curd had low percent improvement in contrast to other traits. This is in line with the above depicted results for selection response of days to visible curd development. Once again it is evident that this trait is controlled mainly by non-additive gene effects. For such trait, half- or full-sib massselection may be more effective than the positive phenotypic mass-selection.

In conclusion, significant improvement for total curd yield and early yield has been achieved through two cycles of directional positive massselection. Apparently, response to selection for days to visible curd was low while the response in curd diameter and the correlated response in curd weight declined sharply after one cycle of positive mass-selection. Thus further selection is not advisable. It is suggested here to maintain the resultant improved population using negative mass-selection while producing its seeds in isolated fields.

\section{Acknowledgment:}

The authors would like to deeply appreciate the support provided by Faculty of Agriculture, Assiut University, Egypt.

Funding statements:

The authors received no external funding for this study.

\section{Conflict of interest:}

The authors declare that they have no conflict of interest.

\section{References}

Abdel-Rahman, M.S.S. (2011) Physiological assessment of flowering response and its application to improve pumpkin production. Ph.D. Dissertation, Assiut University, Assiut, Egypt.
Allard, R.W. (1960) Principles of plant breeding. John Wiley \& Sons, New York - London, 485 p.

Booij, R. and Struik, P.C. (1990) Effects of temperature on leaf and curd initiation in relation to juvenility of cauliflower. Scientia Horticulturae, 44 (3-4), 201 214.

Borghi, B., Accerbi, M. and Corbellini, M. (1998) Response to early generation selection for grain yield and harvest index in bread wheat (Triticum aestivum L.). Plant Breeding, 117, 13-18.

Falconer, D.S. (1989) Introduction to Quantitative Genetics. John Wiley \& Sons, New York, 438 p.

FAOSTAT (2016) Production/Crops, Quantities by Country for Cauliflowers and Broccoli for 2016. Available online: http://faostat.fao.org (accessed on 1/3/2019).

Fujime, Y. (1988) A difference of response to low temperature between cauliflower and broccoli. Acta Horticulturae, 218, XII African Symposium on Hprticultural Crops.

Gizaw, S.A., Garland-Campbell, K. and Carter, A.H. (2016) Use of spectral reflectance for indirect selection of yield potential and stability in Pacific Northwest winter wheat. Field Crops Research, 196, 199-206.

Gomez, K.A. and Gomez, A.A. (1984) Statistical Procedures for Agricultural Research, $2^{\text {nd }}$ ed., John Wiley and Sons, NewYork, 680 p.

Hasan, A.A. (1991) Production of Vegetable Crops. $1^{\text {st }}$ ed., Published by Arab House for Publishing and Distribution. Cairo, Egypt, (in Arabic), 446 p.

Kashiani, P. and Saleh, G. (2010) Estimation of genetic correlations on sweet corn inbred lines using SAS mixed model. Amer. J. Agric. Biol. Sci., 5, 309-314.

Mather, K. (1949) Biometrical Genetics, Methuen and Co., London, 1-162 p.

Miller, P. A., Williams, J.R., Robinson, H.F. and Comstock, R.E. (1958) Estimates of genotypic and environmental variances and covariances in upland cotton and their implications in selection. Agron. J., 50, 126-131.

Mohamed, E.A.A., Mohamed, M.F., ElSayed, E.F. and Haridy, A.G. (2014) Curd yield of cauliflower derived from chilled and hydroprimed seeds. Assiut J. Agric. Sci., 45 (2), 104-112. 
Mohamed, M.F. (1996) Phenotypic variability and selection for predominant pisttillate flower expression in zucchini-type summer squash (Cucurbita pepo L.) cv Eskandarani. $1^{\text {st }}$ EgyptianHung. Hort. Conf., 2, 154-162.

Morsi, M.A. and El-Murabaa, A.I. (1960) Vegetable Plants. Second part: Cultivation of Vegetable Plants. $2^{\text {nd }}$ ed. Egyptian Anglo Library, (in Arabic), $715 \mathrm{p}$.

Peter Visscher, M., William, G.H. and Naomi, R.W. (2008) Heritability in the Genomics Era-concepts and Misconceptions. Nature Reviews Genetics, 9 (4), 255-266.

Rahal-Bouziane, H. and Semiani, Y. (2016) Pearl millet [Pennisetum glaucum (L.) R. Br] landraces from south Algeria: variability, yield components, grain and panicle quality. American J. Agric. Res., 1 (1), $38-46$.
Searle, S.R. (1961) Phenotypic, genotypic and environmental correlations. Biometrics, 17, 474480 .

Steel, R.G.D and Torrie, J.H. (1980) Principles and Procedures of Statistics: A Biometerical Approach. $2^{\text {nd }}$ ed., McGraw-Hill, Inc. New York, 633 p.

Vidyadhar, B., Pooran, C., Swanalatha Devi, I., Vijaya Sai Reddy, M. and Ramachandraiah, D. (2007) Genetic Variability and character association in pearl millet [Pennisetum Glaucum (L.) R. Br.] and their implications in selection. Indian J. Agric. Res., 41 (2), 150-153.

(Received 24/02/2019;

accepted 21/03/2019) 


\section{تقييم التباين والاستجابة للانتخاب للتبكير وحجم القرص الزهري في القرنبيط للصنف السلطاني تحت الظروف البيئية في أسيوط}

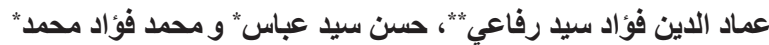

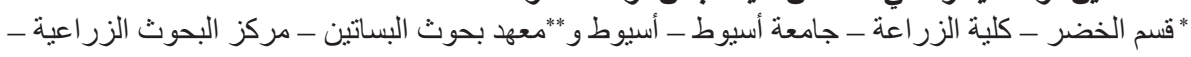
القاهرة - مصر.

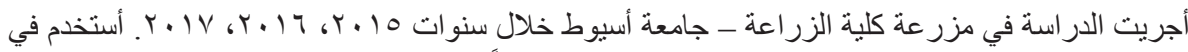

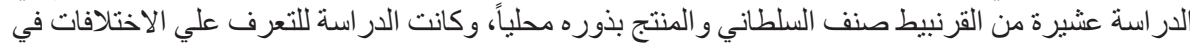

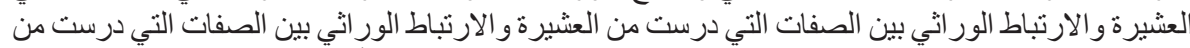

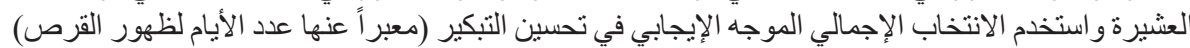

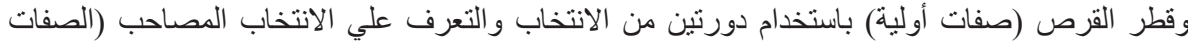
الثانوية) وكذللك كفاءة الانتخاب غير المباثر) بانشر.

أشارت نتائج در اسة الاختلافات إلي وجود تباين كبير (واسع) داخل عشيرة الأساس في عدد الأيام لظهور

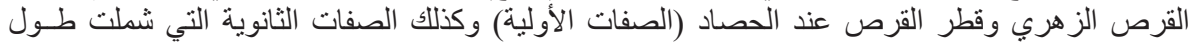

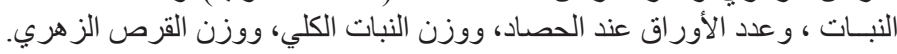

وظهر أن كل الصفات كان لها معامل ارتباط ور اثي ضعيف ذو قيمة سالبة مع عدد الأيام لظهور القرص،

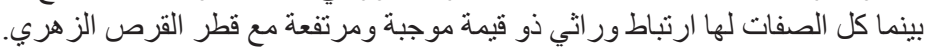

و أظهرت نتائج تقييم الاستجابة للانتخاب (التقدم الور اثي) أن صفة عدد الأيام لظهور القرص ذات استجابة

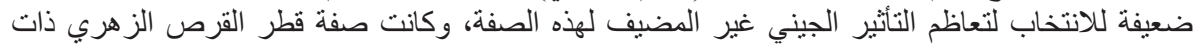

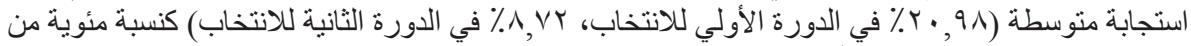

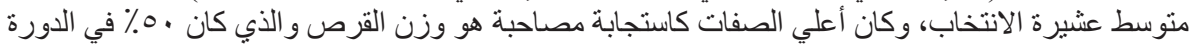

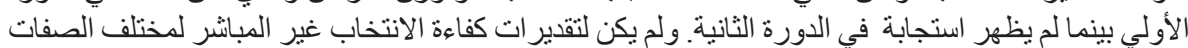

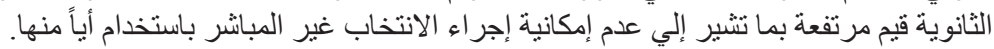

وقد أعطت نتائج التقييم النهائي للعشائر الثلاث (عشيرة الأساس ، عشيرة الدورة الانتخابية الأولي و عشيرة

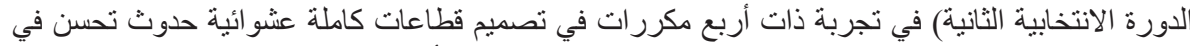

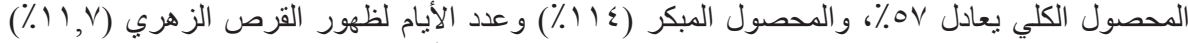

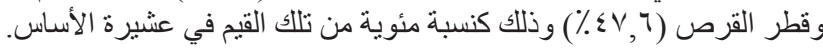

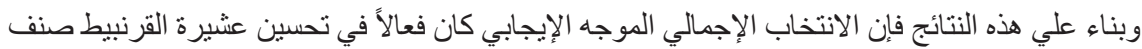

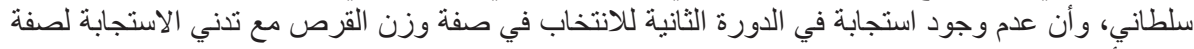

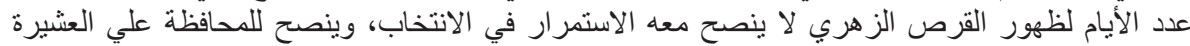

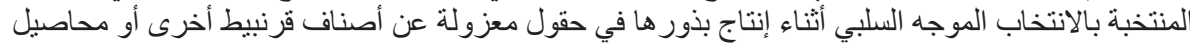

تابعة للنو ع Oleraceae. 